\title{
Investigation of The Effects of Two Nonpharmacological Methods; Using Pacifiers and Maternal Holding, On Pain of Neonates in The Outpatient Clinic and Neonatal Intensive Care Unit
}

\author{
Sağlam Çocuk Polikliniğinde ve Yenidoğan Yoğun Bakım Ünitesinde \\ Farmakolojik Olmayan Ağrı Giderme Yöntemlerinden Emzik Verme ve Anne \\ Kucağının Yenidoğan Ağrısı Üzerine Etkisinin İncelenmesi
}

\author{
Ramazan Gurlu', @Dilek Kahvecioğlu1, @Hatice Tatar Aksoy², AArzu Yılmaz', Bülent Alioğlu' \\ 'Ankara Training And Research Hospital, Pediatrics, Ankara, Turkey \\ 2 TOBB ETÜ Medical Faculty Hospital, Pediatrics, Neonatalogy, Ankara, Turkey
}

\begin{abstract}
Introduction: The most important purpose in neonatal pain management is to minimize the pain felt by newborns and to help the newborn cope with pain. This study planned to examine the effects of two non-pharmacological methods, using pacifiers or maternal holding, on neonates' pain admitted to the outpatient clinic $(\mathrm{OC})$ and hospitalized in the Neonatal Intensive Care Unit (NICU).

Material and Method: Ninety newborns (30 used pacifier, 30 maternal holding,30 control) who applied to the OC and 60 newborns (30 used pacifiers, 30 control) admitted to the NICU were prospectively included in this study. The Neonatal Infant Pain Scale (NIPS) was used to evaluate behavioral responses to pain perception. Physiological parameters of newborns and their duration of crying were also evaluated.

Results: When the NIPS scores were analyzed in OC group during and after the procedure, the lowest score was found in the group using pacifiers $(p<0.001)$. As for the NICU patients, both during and after the procedure, NIPS scores were found to be significantly lower in the pacifier users $(p<0.001)$. It was observed that giving pacifiers and maternal holding had positive effects on physiological parameters and duration of crying in OC patients $(p<0.05)$. No significant difference in the NIPS score was found between OC and NICU group.

Conclusion: This study showed that giving pacifiers and maternal holding during the procedure of blood sampling decreased the NIPS score, restored the changes in physiological parameters and decreased the duration of crying.
\end{abstract}

Keywords: Neonatal pain, NIPS, pacifier, maternal holding
Öz

Amaç: Yenidoğan ağrı yönetiminde en önemli amaç, yenidoğanların hissettiği ağrıyı en aza indirmek ve yenidoğanın ağrı ile baş etmesine yardım etmektir. Bu çalışmada non-farmakolojik yöntemlerden emzik verme ve anne kucağının yenidoğanda ağı üzerine etkilerini incelemek amaçlandı.

Gereç ve Yöntem: Sağlam çocuk polikliniğine ayaktan başvuran 90 yenidoğan (30 emzik, 30 anne kucağı, 30 kontrol) ve aynı dönemde yenidoğan yoğun bakım ünitesinde(YYBÜ) yatarak izlenen 60 yenidoğan (30 emzik, 30 kontrol) çalışmaya dahil edildi. Ağrıya davranışsal yanıtları değerlendirmede Yenidoğan Bebek Ağrı Ölçeği (NIPS) kullanıldı. Ayrıca yenidoğanların fizyolojik parametreleri ile ağlama süreleri de değerlendirildi.

Bulgular: Sağlam çocuk grubunda NIPS skoru işlem sırasında ve sonrasında değerlendirildiğinde emzik verilen grupta en düşük bulundu ( $p<0,001)$. YYBÜ grubunda işlem sırasında ve sonrasında NIPS skorunun emzik verilen grupta anlamlı olarak düşük olduğu saptandı $(p<0,001)$. Emzik verilen grupta daha belirgin olmak üzere emzik verme ve anne kucağının fizyolojik parametreler ve ağlama süreleri üzerine olumlu etkileri olduğu görüldü $(p<0,05)$. Sağlam çocuk ve YYBÜ grubu arasında NIPS skorunda anlamlı bir fark bulunmadı.

Sonuç: Çalışmamızda yenidoğana ağrılı işlem sırasında emzikvermenin ve anne kucağının NIPS skorunu azalttığı, fizyolojik parametrelerdeki değişimi düzelttiği ve ağlama süresini azalttığı görüldü.

Anahtar Sözcükler: Yenidoğanda ağrı, NIPS, emzik verme, anne kucağı 


\section{INTRODUCTION}

One of the most important points in the evaluation of pain is that all attempts causing pain in adults will also cause pain in newborns. Studies have shown that newborns perceive and react to pain even during intrauterine period. ${ }^{[1-3]}$ In the literature, it has been reported that a large number of painful interventions may adversely affect the clinical course of newborns, their behavior, the development of their brains and senses, the adaptation to the external world and the familybaby interaction. ${ }^{[4-7]}$

It is accepted that the conditions causing pain are manifested by negative behavioral, physiological and metabolic responses. ${ }^{[4,5,8]}$ Because of the lack of verbal communication with newborns, pain can be assessed by behavioral and physiological responses. Behavioral responses include crying, facial expressions, breathing patterns, hand and leg movements, wakefulness whereas physiological responses are heart rate, respiration, blood pressure, body temperature and oxygen saturation. Among these, the most obvious response is crying. ${ }^{[8,9]}$

Pain management in newborns can be achieved by pharmacological and non-pharmacological methods. ${ }^{[6-11,13-}$

19] The drugs used as pharmacological methods are limited due to side effects that may occur in the newborn. Therefore, there has been an increased interest in non-pharmacological methods recently. These methods include position change, oral sucrose administration, mathernal holding, breastfeeding, reducing environmental stimulant, rocking, music and touching. ${ }^{[9-11,19]}$

In the intensive care units newborns have to face off numerous stressful or painful diagnostic and therapeutic procedures and uncomfortable interventions. Cumulative early life painful and stressful experiences, during critical neurodevelopmental windows is one of the major unsolved issues of neonatal intensive care. ${ }^{[4,5]}$ In the other hand, infant isolation and parental separation can effect the response of painful stimuli in the NICU. Also in outpatient clinics (OC) newborns have to face off painful procedures. There are a lot of studies that investigate the the effects of pharmacological and nonpharmacological methods during painful procedures in the $\mathrm{NICU}{ }^{[5,7]}$ Is the perception of pain same among newborns admitted to the OC and hospitalized in the NICU? This is an important issue that needs to be clarified.

This study planned to examine the effects of two nonpharmacological methods, using pacifiers or maternal holding, on neonates' pain. Another purpose of this study was to evaluate the differences in the perception of pain among newborns admitted to the outpatient clinic and hospitalized in the NICU. This was the first study that compared pain responses of newborns who applied to the outpatient clinic and hospitalized newborns at NICU and simultaneously assessing respiratory rate and oxygen saturation.

\section{MATERIAL AND METHOD}

A total of 90 newborns who were admitted to the Outpatient Clinic of Our Hospital, between September 2016 and June 2017, were included in the study, and 60 newborns who were hospitalized in the NICU during the same period. The newborns in Outpatient Clinic were randomly divided into three groups during blood sampling, each consisting of 30 newborns, as a pacifier, maternal holding (mother's lap and skin-to-skin contact) and the control group (without the use of a pain relief method in a supine position). The newborns in the NICU were randomly divided into two groups of 30 neonates during blood sampling, as a pacifier and control group (without the use of a pain relief method in a supine position).

This study groups included the newborns who were born between 37-41 weeks of gestation, aged less than 30 days postnatally, and who underwent blood sampling from the back of hand at a one try by venous route were included in the study. Patients with central nervous system disease, who are intubated, who are using antiepileptic and anesthetic drugs or history of such use, with major congenital anomalies and for whom family consent could not be obtained were not included in the study.

Our study was performed receiving the approval consent by the local ethics committee of our hospital, with the consent dated 28.09.2016 and NO.0657. Written consent was obtained from the families for their participation in the study. All procedures were carried out in accordance with the ethical rules and the principles of the Declaration of Helsinki.

The recorded data included: patient's age (day), gestational age (week), gender, anthropometric measurements (weight at birth, length at birth, head circumference at birth, actual weight), reason for blood sampling, type of delivery (Normal Spontaneous Vaginal Delivery, Caesarean Section), hospitalization time (day), hospitalization date (day / month / year), physiological changes before/during/after ( 2 minutes later) blood sampling, duration of procedure, duration of crying and their NIPS scores.

In this study, the blood sampling procedure in the Outpatient Clinic was performed by a same nurse. Likewise, in the NICU, blood was collected by an another nurse. All patients' NIPS scores and vital signs were evaluated and recorded by a same physician at the clinic.

Braun IRT 6020ThermoScan Thermometer was used to measure body temperature before and after the blood collection. The Nihon Kohden BSM-2301K bedside monitor was used to evaluate the changes in oxygen saturation and heart rate before, during and after the blood collection. 21G x 1,5 inch needle was used for blood sampling from the newborns in our hospital.

Behavioral responses of the newborn to pain were evaluated with the Neonatal Infant Pain Scale (NIPS). It is a test that evaluates behavioral responses to painful procedures in preterm and term babies. ${ }^{[12]}$ The Scale consists of 6 behavioral 
sections, including facial expressions, crying, breathing, arm and leg movements, and alertness. While 2 different points (0-1 points) are given for other behaviors except crying, 3 different points (0-1-2) are given for crying. Total score ranges from 0 to 7. High scores indicate that the severity of pain increases. Physiological changes, processing time and duration of crying were synchronously recorded before- during-after the procedure.

SPSS 20.0 for Windows was used for data coding and statistical analysis. This analysis included Pearson's Chi-Square test for the categorical variables, Student-T test for the significance of the difference in mean values between two independent groups with parametric distribution, One Way Anova test for the significance of the difference among more than two groups in terms of average values. Post-hoc tests were performed on the statistically significant results obtained from One Way Anova test.

\section{RESULTS}

Two patient groups 90 patients who were admitted to the Outpatient Clinic and 60 patients in the NICU were included in this study. There was no significant difference between the two groups in terms of gestation week, birth weight, length at birth , head circumference, actual weight, gender and delivery type ( $p>0.05)$. Mean age of blood sampling was $6.5 \pm 5.0$ days in the outpatient children group and $3.4 \pm 2.9$ days in the intensive care group $(p<0.05)$.

In the Outpatient Clinic, NIPS scores were significantly different in three groups during the procedure: the lowest score was obtained in the pacifier group, while the highest score was found in the control group ( $p<0.001)$. After the procedure, NIPS score in the pacifier group was observed significantly lower than the maternal holding and control groups $(p<0.001)$. There was no significant difference between the maternal holding and control groups in terms of NIPS score ( $p>0.05$ ) (Table 1).

There was no significant difference among the groups in terms of heart rate, respiratory rate and oxygen saturation values before the procedure. During the procedure, increase in heart rate was significantly different in all three groups $(p<0.001)$. The increase in heart rate of the pacifier group was lowest while the highest increase was found in the control group. After the procedure, there was no significant difference in the heart rate increase between the maternal holding and control groups ( $p>0.05)$; whereas the increase in heart rate of the pacifier group was significantly lower than that of the other two groups $(p<0.001)$. After the procedure, there was no significant difference between the increase in respiratory rate of the maternal holding and the pacifier group $(p>0.05)$, but the increase in respiratory rate of these two groups was significantly lower than that of the control group $(p=0.001)$. The oxygen saturation was the highest in the pacifier group and the lowest in the control group during the procedure $(p<0.001)$. After the procedure, oxygen saturation was significantly higher in the pacifier group $(p<0.001)$, but there was no significant difference between the maternal holding and control groups ( $p>0.05$ ) (Table 1).

The duration of crying was significantly different in three groups $(p<0.001)$. It was the highest in the control group, while the lowest in the pacifiers group.

In the intensive care group, the NIPS score was significantly lower in the pacifier group both during and after the procedure $(\mathrm{p}<0.001)$ (Table 2).

While there was no significant difference in the heart rate values in the intensive care group before and after the procedure $(p=0.071, p=0.053)$, increase in heart rate was significantly lower in the pacifier group during the procedure $(p<0.001)$. There was no significant difference in respiratory rate in the intensive care group before the procedure $(p=0,628)$, but increase in respiratory rate was significantly lower in the pacifier group after the procedure $(p=0,004)$. While oxygen saturation was significantly higher in the control group in the intensive care group before the procedure $(p=0.022)$, it was significantly higher in the pacifier group during the procedure $(p<0.001)$. There was no significant difference in oxygen saturation values between the groups after the procedure $(p=0.214)$ (Table 2).

In the intensive care group the duration of crying in those who used a pacifier was significantly lower than it was in the control group $(p<0.001)$.

\begin{tabular}{|c|c|c|c|}
\hline $\begin{array}{c}\text { Pacifier }(n=30) \\
M \pm S D\end{array}$ & $\begin{array}{l}\text { Maternal Holding }(n=30) \\
\qquad M \pm S D\end{array}$ & $\begin{array}{c}\text { Control }(n=30) \\
M \pm S D\end{array}$ & $\mathbf{p}^{*}$ \\
\hline $2.0 \pm 2.0$ & $5.6 \pm 1.1$ & $6.5 \pm 0.5$ & $<0.001$ \\
\hline $131.8 \pm 6.7$ & $133.2 \pm 9.8$ & $129.3 \pm 7.0$ & 0.166 \\
\hline $138.6 \pm 6.9$ & $157.1 \pm 11.8$ & $165.3 \pm 9.7$ & $<0.001$ \\
\hline $134.6 \pm 7.5$ & $143.9 \pm 9.0$ & $143.3 \pm 7.6$ & $<0.001$ \\
\hline $35.7 \pm 3.9$ & $36.8 \pm 4.5$ & $39.8 \pm 4.4$ & 0.001 \\
\hline $97.8 \pm 0.3$ & $98.0 \pm 1.0$ & $97.6 \pm 0.9$ & 0.264 \\
\hline $96.4 \pm 1.0$ & $93.7 \pm 2.2$ & $92.2 \pm 2.3$ & $<0.001$ \\
\hline $97.4 \pm 0.8$ & $96.1 \pm 1.8$ & $95.4 \pm 1.6$ & $<0.001$ \\
\hline
\end{tabular}




\begin{tabular}{lccc}
$\begin{array}{l}\text { Table 2. Changes in NIPS score and physiological values in intensive care } \\
\text { group }\end{array}$ & $\begin{array}{c}\text { Pacifier } \\
\text { (n=30) } \\
\text { M } \pm \text { SD }\end{array}$ & $\begin{array}{c}\text { Control } \\
\text { (n=30) } \\
\text { M } \pm \text { SD }\end{array}$ & p* \\
\hline NIPS during procedure & $2.4 \pm 1.7$ & $6.2 \pm 1.0$ & $\mathbf{0 . 0 0 1}$ \\
NIPS after procedure & $0.6 \pm 0.8$ & $3.4 \pm 1.8$ & $<\mathbf{0 . 0 0 1}$ \\
Heart rate before procedure (beat/mn) & $139.1 \pm 17.0$ & $131.4 \pm 15.0$ & 0.071 \\
Heart rate during procedure (beat/mn) & $145.4 \pm 17.1$ & $162.7 \pm 13.8$ & $<\mathbf{0 . 0 0 1}$ \\
Heart rate after procedure (beat/mn) & $139.8 \pm 15.1$ & $147.8 \pm 16.0$ & 0.053 \\
Respiratory rate before procedure & $37.3 \pm 4.6$ & $38.2 \pm 8.5$ & 0.628 \\
Respiratory rate after procedure & $38.3 \pm 5.1$ & $44.1 \pm 8.1$ & $\mathbf{0 . 0 0 4}$ \\
$\mathrm{SpO}_{2}$ before procedure (\%) & $96.7 \pm 2.2$ & $97.8 \pm 1.1$ & $\mathbf{0 . 0 2 2}$ \\
$\mathrm{SpO}_{2}$ during procedure (\%) & $94.8 \pm 2.4$ & $92.1 \pm 2.9$ & $<\mathbf{0 . 0 0 1}$ \\
$\mathrm{SpO}_{2}$ after procedure (\%) & $95.8 \pm 2.2$ & $95.0 \pm 2.6$ & 0.214 \\
\hline
\end{tabular}

$\mathrm{M} \pm \mathrm{SD}$ : Mean \pm standard deviation, $\mathrm{mn}$ : minute, $\mathrm{SpO}_{2}$ : oxygen saturation, NIPS: Neonatal Infant Pain Scale, *: Student $t$ Test, $p<0.05$ was considered statistically significant

During and after the procedure, no significant difference in the NIPS was found between the pacifiers group in outpatient and intensive care group (in order of $p=0.734$, $\mathrm{p}=0.218$ ) (Table 3).

Table 3. Changes in NIPS scores between the pacifiers group in outpatient clinic and in the intensive care groups

\begin{tabular}{|c|c|c|c|}
\hline & $\begin{array}{l}\text { Outpatient clinic } \\
\text { pacifier group } \\
(n=30)\end{array}$ & $\begin{array}{c}\text { Intensive care } \\
\text { pacifier group } \\
\quad(n=30)\end{array}$ & $\mathbf{p}^{*}$ \\
\hline & $\mathrm{M} \pm \mathrm{SD}$ & $\mathrm{M} \pm \mathrm{SD}$ & \\
\hline NIPS during procedure & $2.6 \pm 2.0$ & $2.4 \pm 1.7$ & 0.734 \\
\hline NIPS after procedure & $0.3 \pm 0.8$ & $0.6 \pm 0.8$ & 0.218 \\
\hline
\end{tabular}

M \pm SD: Mean \pm standard deviation, NIPS: Neonatal Infant Pain Scale, *: Student t test, $p<0.05$ was considered statistically significant

There were no significant differences in the increase in heart rate, increase in respiratory rate and oxygen saturation values between the groups of patients who were given pacifiers in the outpatient clinic and neonatal intensive care groups.

\section{DISCUSSION}

Many painful medical interventions are often used for newborns who need treatment and care especially in NICU. Newborns whose pain is controlled can have a stronger immune system, shorter hospital stay, and increased growth rates. ${ }^{[5,6]}$

Reduction of pain by a pacifier can be achieved with the help of sucking reflex and sense of touch. It is reported that the feeling that babies receive with sucking is a superior feeling and sucking a pacifier is a satisfying feeling in a child, causing distraction from the pain. Therefore, using pacifiers in children younger than three months is effective and easy to use for reducing pain. ${ }^{[13-16]}$

Akdovan evaluated the behavioral response and physiological changes in pain with NIPS before, during and after taking a heel blood sample, by separating newborns into three groups of 30 patients (pacifier, holding in arms, control). As a result of the study, the NIPS score was significantly lower in the pacifier group compared to the holding in arms and the control group, while there was no significant difference in the NIPS score in the holding in arms and control groups. ${ }^{[16]}$ In our study, in accordance with this study the use of pacifiers significantly reduced the NIPS score in both OC and NICU patients.

Campos carried out a study on 60 newborns that examined the effect of rocking and pacifiers on decreasing the pain stress while taking a heel blood sample. He found out that pacifiers significantly decreased the changes in heart rate in comparison to rockings. In our study, similar to Campos's, it was seen that giving a pacifier to newborns during the painful procedure had positive effects on increased heart rate compared to the control group and it was found statistically significant. $^{[13]}$

Liaw et al. studied the effect of using pacifiers or sucrose on physiological parameters in newborns who were vaccinated against hepatitis. ${ }^{[15]}$ The study included 165 newborns and the newborns were divided into 3 groups as pacifier, sucrose and control group. At the end of the study, they found that the increase in heart rate and respiratory rate were significantly lower in both groups compared to the control group. As a result of this study, Liaw et al. suggested using of sucrose or a pacifier in a newborn during the painful interventional procedure. Although the patients evaluated in that study underwent intramuscular injection method for a painful procedure, pacifiers had positive effects on heart rate and respiratory rate compared to control group, which is similar to our study.

In 2000, Corbo et al. found that nonnutritive sucking had no effect on respiratory rate or transcutaneous oxygen tension, but reduced the time of crying and the heart rate increase during the procedure. ${ }^{[14]}$ In our study pacifiers significantly reduced duration of crying and heart rate, respiratory rate during and after procedure in OC patients. So we suggest that pacifier using have positive effects on physiological parametres.

Although maternal holding is an important intervention that provides relief, the responses during this procedure should be observed. Despite the fact that taking the baby on the maternal holding may reduce the sensitivity to pain, a rigid holding may cause excessive stimulation of the baby and hypersensitivity by increasing the basal metabolic rate. In addition, a slight, inaccurate touch may cause agitation. ${ }^{[17]}$

Phillips et al. compared the analgesic effect of breastfeeding, maternal holding and pacifier in 96 newborns in their study. ${ }^{[18]}$ As a result of the study, it was determined that the breastfeeding group and the pacifier with maternal holding group were crying less than the only pacifier group. Despite the differences in the methods, in our study it was observed that the maternal holding had a positive effect on the duration of crying and physiological parametres.

The environment of NICU is stressful for babies. Separation from parents and experiencing recurrent pain constitutes the most important stressful events. Since babies followed 
up in intensive care will be candidates for chronic pain in the future. However it is thought that the pain threshold of patients admitted to the outpatient clinic and intensive care patients may be different. So in this study, patients who were admitted to Outpatient Clinic and patients who were in NICU were compared in terms of the differences in the perception of pain in the newborns, but no statistically significant data were obtained. In our study mean age of blood sampling was earlier in the intensive care group. The NIPS score differences may not have been found between the two groups; as the NICU group have not been exposed to reccurrent painful procedure.

In this study, according to the institutional rules and conditions maternal holding group was not possible taken in the NICU. In addition, the fact that the mothers of newborns in the NICU could not be reached at any time was effective in taking this decision. This is one of the limitations of our study. We couldn't adressed the reason for admission to the hospital and reason for blood sampling. This is another limitation of our study.

\section{CONCLUSION}

We found that pacifiers helped to reduce the NIPS score, restored the changes in physiological parameters and decreased the duration of crying during the painful procedures. In addition, we found that the maternal holding reduced the NIPS score, restored the change in physiological parameters and decreased duration of crying, though not as much as a pacifier. The maternal holding, though not as effective as a pacifier, can be applied with the pacifier or alone if the doctor or the parents do not want the use of the pacifier. On the basis of all these, it shall be beneficial to give a pacifier to all infants who can suck a pacifier during painful procedures.

As seen in our study, pain is not negligible in newborns and pain level should be determined by using pain scale during interventional procedures to be applied to newborns. Each unit should establish a care plan with non-pharmacological and pharmacological methods, and necessary interventions should be made to reduce pain. Correct pain management will support the development of infants and reduce stress symptoms.

\section{ETHICAL DECLARATIONS}

Ethics Committee Approval: Permission for the study was obtained from the Education, Planning and Coordination Board of Ankara Training and Research Hospital at the meeting numbered 658, dated 05.10.2016, with the decision numbered 5526.

Informed Consent: Written consent was obtained from the families for their participation in the study.

Referee Evaluation Process: Externally peer-reviewed.

Conflict of Interest Statement: The authors have no conflicts of interest to declare.
Financial Disclosure: The authors declared that this study has received no financial support.

Author Contributions: All of the authors declare that they have all participated in the design, execution, and analysis of the paper, and that they have approved the final version.

Note: This study was presented at the 4th International Neonatology Association Conference and the 26th National Neonatology Congress.

\section{REFERENCES}

1. Smith RP, Gitau R, Glover V et al. Pain and stress in the human fetus. Eur J Obstetr Gynecol Reprod Biol 2000;92:161-5.

2. Perry M, Tan Z, Chen J et al. Neonatal Pain: Perceptions and Current Practice. Crit Care Nurs Clin North Am. 2018;30(4):549-61.

3. Simons SHP, Tibboel D. Pain perception development and maturation. Semin Fetal Neonatal Med 2006;11:227-31.

4. Walker SM. Long-term effects of neonatal pain. Semin Fetal Neonatal Med. $2019 ; 24(4): 101005$.

5. Cong $\mathrm{X}, \mathrm{Wu} \mathrm{J}$, Vittner $\mathrm{D}$ et al. The impact of cumulative pain/stress on neurobehavioral development of preterm infants in the NICU. Early Hum Dev 2017;108:9-16

6. Committee on fetus and newborn and section on anesthesiology and pain medicine. Prevention and Management of Procedural Pain in the Neonate: An Update. Pediatrics. 2016;137(2):e20154271.

7. Squillaro A, Mahdi EM, Tran $N$ et al. Managing Procedural Pain in the Neonate Using an Opioid-sparing Approach. Clin Ther. 2019;41(9):170113

8. Field T. Preterm newborn pain research review. Infant Behav Dev. 2017;49:141-50.

9. Dur S, Balci S. Assessing Neonatal Pain, Duration of Crying and Procedure Time following Use of Automatic or Manual Heel Lances: A Randomized Controlled Study. J Trop Pediatr 2018;64(6):488-94.

10. Harrison D, Reszel J, Bueno $M$ et al. Breastfeeding for procedural pain in infants beyond the neonatal period. Cochrane Database Syst Rev. 2016;10(10):CD011248.

11. Cignacco E, Hamers JPH, Stoffel L et al. The efficacy of non-pharmacological interventions in the management of procedural pain in preterm and term neonates. A systematic literature review. Eur J Pain 2007;11:139-52.

12. Lawrence J, Alcock D, McGrath P et al. The devolopment of a tool to assess neonatal pain. Neonatal Network 1993;12(6):59-64.

13. Campos RG. Rocking and pacifiers: Two comforting interventions for heelstick pain. Res Nurs Health 1994;17(5):321-31.

14. Corbo MG, Mansi G, Stagni A et al. Nonnutritive Sucking during Heelstick Procedures Decreases Behavioral Distress in the Newborn Infant. Biology of the Neonate 2000:77(3):162-167.

15. Liaw JJ, Zeng WP, Yang L et al. Nonnutritive sucking and oral sucrose relieve neonatal pain during intramuscular injection of hepatitis vaccine. J Pain Symptom Manag 2011;42:918-30.

16. Akdovan T. Sağlıklı yenidoğanlarda ağrının değerlendirilmesi, emzik verme ve kucağa alma yönteminin etkisinin incelenmesi (Tez). İstanbul: Marmara Üniversitesi Sağlık Bilimleri Enstitüsü; 1999.

17. Merenstein GB, Gardner SL. Handbook of neonatal intensive care. 4th ed. Mosby, St. Louis, MO; 1998.

18. Phillips RM, Chantry CJ, Gallagher MP. Analgesic effects of breast-feeding or pacifier use with maternal holding in term infants. Ambul Pediatr 2005;5(6):359-64.

19. Stevens B, Yamada J, Ohlsson A et al. Sucrose for analgesia in newborn infants undergoing painful procedures. Cochrane Database Syst Rev. 2016;7(7):CD001069. 